\title{
Peranan Strategi Pemasaran Untuk Meningkatkan Tingkat Minat Belajar Pada Sempoa SIP Dempo Palembang.
}

\author{
Wiwin Winarsih ${ }^{1}$, M. Didi Wahyudi ${ }^{2}$, Aries Veronica ${ }^{3}$ \\ ${ }^{1}$ Fakultas Ekonomi Universitas Tamansiswa, wiwinw1961@gmail.com \\ ${ }^{2}$ Fakultas Ekonomi Universitas Tamansiswa, wdidi79@gmail.com \\ ${ }^{3}$ Faultas Ekonomi Universitas Tamansiswa, ariesveronica78@gmail.com
}

\begin{abstract}
ABSTRAK
Penelitian ini bertujuan untuk mengetahui penerapan strategi pemasaran dan menemukan bauran pemasaran yang tepat yang meliputi $7 \mathrm{p}$ (produk, harga, tempat, promosi, orang, proses, bukti fisik) pada Bimbingan Belajar Sempoa SIP Cabang Dempo Palembang untuk mencapai target pasarnya. Teknik analisis yang digunakan dalam penelitian ini adalah analisis kualitatif dengan metode pengumpulan data, wawancara dan studi pustaka. Hasil penelitian menunjukkan bahwa terdapat kurang signifikannya jumlah peserta bimbingan belajar sesuai dengan target yang telah ditetapkan oleh Sempoa SIP. Hal ini terjadi karena kurangnya permintaan dan kendala dari beberapa sektor. Di masa depan, Sempoa SIP Dempo Palembang perlu mempertahankan strategi suksesnya dan mungkin ingin mempertimbangkan pengurangan harga serta memprioritaskan kegiatan di berbagai sekolah dan promosi media sosial dengan cara yang kreatif dan inovatif.
\end{abstract}

Kata Kunci : Bimbingan Belajar, Bauran Pemasaran, Media Promosi

\begin{abstract}
This study aims to know the application of marketing strategy and finding proper marketing mix that includes $7 p$ (product, price, place, promotion, people, process, physical evidence) at Tutoring Agency Sempoa SIP Dempo Palembang Branch to reach its target market. The analysis techniques used in this study is qualitative analysis by data collection methods, interview and library research. The results showed that there is lack of significance number of participants tutoring in accordance with predetermined target by Sempoa SIP. This occurs because of a lack of demand and obstacles from several sectors. In the future, Sempoa SIP Dempo Palembang needs keep its succeeding strategy and might want to consider price reduction as well prioritization of activities in the different schools and social media promotion in creative and innovative ways.
\end{abstract}

Keywords : Tutoring Agency, Marketing Mix, Promotion Media

\section{A. PENDAhULUAN}

Pemasaran menurut Kotler dan Amstrong (2004) adalah sebuah proses sosial manajerial, dimana individu-individu dan kelompok- kelompok memperoleh apa yang mereka butuhkan dan mereka inginkan, melalui penciptaan dan pertukaran produk serta nilai dengan pihak lain. kegiatan pemasaran yang di lakukan oleh perusahaan dalam usaha nya sebagai bentuk untuk mempertahankan kelangsungan hidup perusahaan dalam persaingan usaha yang semakin ketat dan untuk mengembangkan usaha nya. Strategi pemasaran diarahkan untuk meningkatkan kemungkinan atau frekuensi perilaku konsumen, seperti peningkatan kunjungan pada toko tertentu atau keputusan pembeli produk tertentu. Hal ini dapat dicapai dengan mengembangkan dan menyajikan bauran pemasaran yang diarahkan pada pasar sasaran yang dipilih, Setiadi (2010).

Sempoa SIP Dempo Palembang merupakan anak perusahaan dari GROUP SIP INDONESIA yang bergerak dalam bidang perusahaan jasa lebih spesifik nya perusahaan jasa dalam dunia pendidikan. Perusahaan yang bergerak dalam dunia pendidikan seperti Sempoa Sip Dempo Palembang memiliki banyak tantangan yang 
harus dihadapi, sehingga perusahaan harus dapat menerapkan strategi pemasaran yang tepat agar menarik minat konsumen untuk menggunakan jasa yang di tawarkan. Target penjualan produk (jasa) tidak tercapai disebabkan banyak nya perusahaan pesaing yang menawarkan jasa sejenis dengan promosi yang lebih menarik. sehingga konsumen mempunyai pilihan untuk memilih jasa mana yang akan digunakan berdasarkan selera konsumen.

Untuk mencapai keberhasilan usaha diperlukan strategi pemasaran dalam merealisasikan tujuan tersebut agar perusahaan mampu bertahan dan mampu meningkatkan penjualannya tiap periode. Salah satu cara yang dapat dilakukan oleh perusahaan adalah mampu melihat peluang yang ada. Bauran pemasaran merupakan alat bagi pemasar yang terdiri atas berbagai unsur suatu program pemasaran yang perlu dipertimbangkan agar implementasi strategi pemasaran dan positioning yang diterapkan dapat berjalan sukses (Lupiyodi dan Hamdani, 2006). Bauran Pemasaran dikenal dengan 7P yaitu product, price, place, promotion, people, physical evidence dan process.

Penelitian yang dilakukan oleh Kereh dkk (2018) mengatakan bahwa strategi pemasaran perusahaan dengan menggunakan bauran pemasaran sangat mempengaruhi peningkatan penjualan perusahaann. Hal serupa juga sejalan dengan penelitian yang dilakukan oleh Lupiyodi dan Hamdani (2006), Silvana (2012), serta Monigir dan Ogi (2016). Berdarkan hal tersebut, penulis tertarik untuk melakukan penelitian yang sama untuk mengetahiu bagaimana peranan strategi pemasaran untuk meningkatkan tingkat minat belajar pada Sempoa Sip Dempo Palembang.

\section{B. KAJIAN TEORI}

\section{1) Pengertian Pemasaran}

Pemasaran menurut Kotler \& Keller (2009) diartikan sebagai hasil prestasi kerja kegiatan usaha yang langsung berkaitan dengan mengalirnya barang atau jasa dari produsen kekonsumen. Menurutnya, pemasaran adalah satu fungsi organisasi dan seperangkat proses untuk menciptakan, mengkomunikasikan, dan menyerahkan nilai kepada pelanggan dan mengelola hubungan pelanggan dengan cara menguntungkan organisasi dan para pemilik sahamnya. Menangani proses pertukaran ini membutuhkan banyak kerja dan keterampilan. Manajemen pemasaran terjadi ketika setidaknya satu pihak dalam sebuah pertukaran potensial berfikir tentang cara-cara untuk mencapai respons yang diinginkan pihak lain. Karena kita memandang manajemen pemasaran (marketing management) sebagai seni dan ilmu memilih pasar sasaran dan meraih, mempertahankan, serta menumbuhkan pelanggan dengan menciptakan, menghantarkan dan mengomunikasikan nilai pelanggan yang unggul.

\section{2) Pengertian Jasa}

Menurut Kotler dan Amstrong (2004) jasa adalah setiap tindakan atau kegiatan yang dapat ditawarkan oleh satu pihak kepada pihak lain, yang pada dasarnya tidak berwujud dan tidak mengakibatkan kepemilikan apapun produknya bisa berkaitan dengan produk fisik atau tidak. Jasa mempunyai empat karakteristik utama yang sangat mempengaruhi pemasaran, dimana karakteristik jasa tersebut dapat di artikan : 1) Intangible (tidak berwujud); 2) Inseparability (tidak dapat di pisahkan); 3) Variability (bervariasi); 4) Perishability (tidak tahan lama) 


\section{3) Lembaga Bimbingan Belajar}

Bimbingan belajar merupakan salah satu bentuk kegiatan ekstrakurikuler yang dilakukan diluar sekolah atau di tengah-tengah masyarakat yang bertujuan untuk membantu kebutuhan manusia akan pendidikan. Para guru pembimbing berupaya untuk memfasilitasi agar siswa dapat mengatasi kesulitan belajarnya dan sampai pada tujuan yang diharapkan. Lembaga pendidikan nonformal adalah setiap upaya pendidikan dalam arti luas yang di dalamnya terdapat komunikasi yang teratur dan terarah, diselenggarakan di luar subsistem pendidikan formal, sehingga seseorang atau kelompok memperoleh informasi, latihan,dan bimbingan sesuai dengan tingkatan usia dan kebutuhan hidupnya.

Organisasi dan manajemen lembaga bimbingan belajar sangat sederhana, fleksibel dan struktur organisasinya tergantung kesibukan masing-masing lembaga (cabang). Secara lengkap organisasi lembaga bimbel terdiri dari Manajer Cabang atau Direktur, Bagian Akademik, Koordinator Marketing, bagian Administrasi, Bagian Keuangan, yang masing-masing dijabat oleh satu orang. Dimasing-masing bagian dapat di bantu 1 - 2 orang orang staf tergantung dari banyaknya kegiatan lembaga. Dibawah jenjang Direktur juga ada kelompok pendidik yang biasa disebut Tutor/Tentor/Instruktur yang jumlahnya tergantung pada jumlah siswa peserta kursus, jumlah jenjang kelas sekolah umum dan jumlah sekolah yang dilayani.

Fungsi dari bimbingan belajar adalah sebagai berikut :

a. $\quad$ Fungsi pencegahan (preventive function)

Bimbingan belajar berupayah untuk mencegah atau mereduksi kemungkinan timbulnya masalah.

b. Fungsi penyaluran ( Distributive Function )

Fungsi penyaluran berarti menyediakan kesempatan kepada siswa untuk menyalurkan bakat dan minat sehingga mencapai hasil belajar yang sesuai dengan kemampuannya.

c. Fungsi Penyesuaian (Adjustive Function)

Guru pembimbing berupaya membantu siswa menyerasikan program pengajaran agar dapat menyesuaikan diri, memahami diri dengan tuntutan program pengajaran yang sedang dijalaninya. Atas dasar tersebut penyesuaian memiliki sasaran :

1) Membantu siswa agar dapat menyesuaikan diri terhadap tuntutan program pendidikan.

2) Membantu siswa menyerasikan program-program yang dikembangkan dengan tuntutan pengajaran.

d. Fungsi Perbaikan ( Remedial Function )

Tugas para guru-guru pembimbing adalah upaya untuk memahami kesulitan belajar, mengetahui faktor penyebab, dan bersama siswa menggali solusinya.

e. $\quad$ Fungsi Pemeliharaan ( Maintencance and Development Function )

Belajar dipandang positif harus tetap dipertahankan, atau bahkan harus ditingkatkan agar tidak mengalami kesulitan lagi.

\section{4) Bauran Pemasaran (Marketing Mix)}

Jika kita berbicara tentang strategi pemasaran maka erat hubungan dengan teori 7 P yaitu Product, Price, Place, Promotion, People, Process, Physical evidence. (Kotler dan Amstrong, 2004) 


\section{Product (produk)}

Kotler dan Amstrong mendefinisikan produk adalah segala sesuatu yang dapat ditawarkan kepasar untuk perhatian, akuisi, penggunaan dan konsumsi yang dapat memuaskan keinginan atau kebutuhan. Dalam arti luas, produk mencakup barang fisik, jasa, orang, organisasi, gagasan atau gabungan dari semua itu. Jasa adalah produk yang terdiri atas aktifitas, manfaat yang ditawarkan untuk dijual.

2. Price (harga)

Harga merupakan pengorbanan ekonomis yang dilakukan pelanggan untuk memperoleh produk atau jasa. Selain itu harga salah satu faktor penting konsumen dalam mengambil keputusan untuk melakukan transaksi atau tidak (Beaver dan Engel, 1996). Harga dikatakan mahal, murah atau biasa-biasa saja dari setiap individu yang di latarbelakangi oleh lingkungan kehidupan dan kondisi individu (Schifman dan kanuk, 2008).

3. Place (lokasi)

Lokasi berarti berhubungan dengan di mana perusahaan harus bermarkas dan melakukan operasi atau kegiatannya. Dalam hal ini ada tiga jenis interaksi yang mempengaruhi lokasi, yaitu :

a. Konsumen mendatamgi pemberi jasa (perusahaan)

b. Pemberi jasa mendatangi konsumen

c. Pemberi jasa dan konsumen tidak bertemu secara langsung

4. Promotion (promosi)

Promosi (Swastha\&Sukotjo: 2002) adalah kegiatan mengkomunikasikan informasi dari penjual kepada konsumen atau pihak lain dalam saluran penjualan untuk mempengaruhi sikap dan perilaku. Melalui periklanan suatu perusahaan mengarahkan komunikasi persuasif pada pembeli sasaran dan masyarakat melalui media-media yang disebut dengan media massa seperti Koran, majalah, tabloid, radio, televis dan direct mail. Media promosi yang dapat digunakan pada bisnis ini antara lain (1) Periklanan, (2) Promosi penjualan, (3) Publisitas dan hubungan masyarakat, dan (4) Pemasaran langsung. Penentuan media promosi yang akan digunakan didasarkan pada jenis dan bentuk produk itu sendiri.

5. People (orang)

Yang dimaksud people disini adalah karyawan penyedia jasa layanan maupun penjualan, atau orang-orang yang terlibat secara langsung maupun tidak langsung dalam proses layanan itu sendiri, misalnya dalam jasa kursus bimbel diantaranya ada para guru dan admin.Orang-orang merupakan unsur penting, baik dalam produksi maupun penyampaian kebanyakan jasa. Orang-orang secara bertahap menjadi bagian diferensiasi yang mana perusahaan-perusahaan jasa mencoba menciptakan nilai tambahan dan memperoleh keunggulan kompetitif.

6. Process (proses)

Proses adalah kegiatan yang menunjukkan bagaimana pelayanan diberikan kepada konsumen selama melakukan pembelian barang. Pengelola usaha melalui front liner sering menawarkan berbagai macam bentuk pelayanan untuk tujuan menarik konsumen. Fasilitas jasa konsultasi gratis, pengiriman produk, credit card, card member dan fasilitas layanan yang berpengaruh pada image perusahaan.

7. Physical evidence (sarana fisik)

Phisycal evidance yaitu sejumlah sarana dan prasarana yang di miliki perusahaan dalam menjalankan aktifitas nya sehingga berbagai tawaran yang di tunjukkan pada pasar sasarannya dapat diterima secara efektif dan efisien, yakni antara lain fasilitas parkir, ruang tunggu, wifi dan lainya. Phisycal evidance mencakup fitur 
fisik yang mencerminkan kualitas layanan,misal nya dekorasi, seragam karyawan dan kualitas komunikasi.

\section{METODOLOGI PENELITIAN}

Penelitian ini dilakukan di Sempoa Sip Dempo Palembang yang berlokasi di Jl. Menumbing No.173, Kepandean Baru, Kec. Ilir Timur I, Palembang. Metode pengumpulan data dilakukan dengan wawancara dan dokumentasi. Teknik analisis yang digunakan adalah analisis deskriptif.

\section{HASIL PENELITIAN DAN PEMBAHASAN}

Saat ini dengan berkembangnya jaman, dalam mencapai sebuah tujuan perusahaan dan menjaga keberlangsungan usahanya serta memasarkan produk jasa kepada calon konsumen diperlukan strategi bisnis. Sehingga perusahaan harus memiliki strategi-strategi pemasaran yang jitu untuk menunjang keberhasilan dalam memasarkan produknya. Dalam membuat strategi pemasaran maka perusahaan harus menerapkan teori marketing mix.

Marketing mix merupakan variabel terkendali yang bisa digabungkan untuk mencapai tujuan yang diharapkan dan pasar sasaran. Marketing mix yang diterapkan oleh perusahaan satu dengan perusahaan lainnya berbeda-beda tergantung perusahaan tersebut bergerak dibidang jasa atau produk.

\section{Strategi Produk}

Dalam konteks jasa pendidikan produk adalah jasa yang ditawarkan kepada pelanggan berupa reputasi, prospek dan variasi pilihan. Sempoa SIP Dempo Palembang harus mampu bersaing dalam hal persaingan jasa pendidikan untuk keberlangsungan usahanya. Sempoa SIP Dempo Palembang perlu membangun reputasi yang baik, Sempoa sip pun harus bisa menciptakan prospek dan mutu pendidikan yang baik, sehingga konsumen tertarik untuk menggunakan produk Sempoa SIP. Sempoa SIP Dempo Palembang perlu membuat produk mereka berperan dalam pembelajaran disekolah, Sempoa SIP perlu menawarkan kepada konsumen bahwa produk Sempoa SIP dapat berperan terhadap pembelajaran lebih tepat nya pelajaran matematika, karena dengan belajar Sempo SIP siswa akan terbiasa dengan bilangan angka dan berhitung cepat atau dengan kata lain Sempoa SIP dapat menghindari phobia angka terhadap siswa.Didalam sebuah produk (jasa) konsumen pasti akan melihat dari segi kualitasnya. Sempoa SIP akan diminati jika kualitas yang dimiliki baik, karena produk merupakan penentu pertama untuk mendapatkan hati para konsumen atau pelanggan, para konsumen akan tertarik jika produk (jasa) yang ditawarkan oleh Sempoa SIP mempunyai kualitas, kinerja atau sifat-sifat inovasi terbaik.

\section{Strategi Harga}

Harga merupakan salah satu bagian yang sangat penting dalam pemasaran suatu produk. Harga dapat menjadi suatu hal lain untuk dipertimbangkan oleh konsumen dalam menentukan suatu produk. Dalam persaingan antar perusahaan dan penjualan pasar, harga akan memberikan hasil memuaskan bagi perusahaan, mengetahui untung dan ruginya perusahaan, dengan harga Sempoa SIPbisa menciptakan pendapatan untuk membayar biaya operasional perusahaan seperti gaji karyawan, tagihan listrik, dan sebagainya. Jadi dalam hal ini harga berperan penting dalam memajukan atau memundurkan suatu perusahaan. 
Dalam penjelasan tersebut, pihak Sempoa SIP Dempo Palembang perlu menciptakan harga yang tepat dalam menetapkan keuntungan yang sewajarnya. Menetapkan harga terlalu tinggi akan menyebabkan penjualan akan menurun, namun jika harga terlalu rendah akan mengurangi keuntungan yang dapat diperoleh oleh Sempoa SIP. Apabila Sempoa SIP salah dalam menentukan harga maka akan berdampak keterpurukan, Sempoa SIP akan mengalami kegagalan yang mengakibatkan konsumen pergi menghindar, hal ini bisa membuat Sempoa SIP menutup usahanya. Apalagi banyak produk (jasa) merk lain yang berlomba-lomba menarik konsumen untuk menggunakan produk (jasa) mereka . adapun faktor-faktor yang mempengaruhi baik secara langsung menyangkut pendapatan, harga, biaya pemasaran. Sempoa SIP akan memberikan potonngan harga berupa promosi dan diskon kepada konsumen.

Jika faktor-faktor tersebut diperhatikan, maka kepuasan yang diharapkan konsumen akan terpenuhi. Adapun tujuan penetapan harga, yaitu :

a) mendapatkan keuntungan yang sebesar-besarnya, dengan menetapkan harga yang kompetitif maka Sempoa SIP akan mendulang untung yang optimal.

b) Keberlangsungan Sempoa SIP, dari kentungan yang di dapat sempoa sip akan digunakan untuk biaya operasional perusahaan, contohnya untuk gaji karyawan, tagihan listrik, tagihan air bersih, biaya trasnportasi, dan sebagainya

c) Menggapai ROI (Return On Investment), sempoa sip pasti menginginkan balik modal dari investasi yang ditanamkan pada perusahaan sehingga penetapan harga yang tepat akan mempercepat tercapainya modal kembali.

d) Menguasai pangsa pasar dengan menetapkan harga lebih rendah dibandingkan produk pesaing, hal ini dapat mengalihkan perhatian konsumen dari produk kompetitor yang ada dipasaran.

e) Mempertahankan status ketika perusahaan memiliki pasar tersendiri, maka perlu adanya pengaturan harga yang tepat agar dapat tetap mempertahankan pangsa pasar yang ada.

\section{Strategi Tempat (Place)}

Tempat merupakan alat atau saluran yang digunakan untuk mengantarkan produk atau jasa dalam melayani pasar sasaran, selain itu tempat merupakan alat perusahaan dalam memberikan pelayanan serta fasilitas kepada konsumen sehingga dapat menjadi wadah melakukan transaksi.

Dalam hal ini Sempoa SIP Dempo Palembang sebagai penyedia jasa dimana konsumen yang mendatangi pemberi jasa,Sempoa SIP sebagai pemberi jasa akan lebih efektif jika lokasi mudah dicapai dengan kendaraan umum hal ini cukup berperan sebagai bahan pertimbangan calon siswa untuk bergabung dengan Sempoa SIP Dempo Palembang. Selain itu keamanan tempat atau lokasi yang dituju dalam hal ini perlu dipertimbangkan faktor-faktor seperti, akses, vasibilitas, lalu lintas, dan tempat parkir. Berdasakan hasil penelitian bahwa tempat atau lokasi lokasi Sempoa SIP Dempo Palembang cukup strategis karena mudah dijangkau oleh masyarakat, jalan menuju tempat kursus pun mudah diakses oleh transportasi umum maupun pribadi serta keamanan menuju lokasi dan lingkungan aman dan nyaman.

\section{Strategi Promosi}

Kebijakan promosi yang dilakukan Sempoa SIP Dempo Palembang adalah dalam rangka mencapai mewujudkan tingkat pasar yang akan dituju. Dipihak lain 
dalam kondisi persaingan produk yang sama terhadap kompetitor lain semakin ketat ditambah pula keterbatasan luas pasar dan produk menyebabkan semakin sedikit pula konsumen yang dapat diserap oleh perusahaan Sempoa SIP Dempo Palembang.

Promosi merupakan usaha Sempoa SIP untuk mempengaruhi calon pembeli dengan cara merayu (persuasive communication) calon pembeli,melalui pemakaian segala unsur acuan pemasaran. jika perusahaan melakukan kegiatan promosi maka akan timbul biaya promosi, dalam hal ini biaya promosi yang dikeluarkan oleh Sempoa SIP nominalnya cukup besar, wajar jika Sempoa SIP Dempo Palembang memasang target tinggi. Oleh karena itu Sempoa SIP perlu mengoptimalkan sasaran mana yang akan dituju. Ada beberapa unsur promosi yang telah dilakukan oleh pihak Sempoa SIP Dempo Palembang yaitu periklanan melalui brosur dan spanduk namun hal ini perlu di perbanyak lagi karena spanduk yang di pasang oleh Sempoa SIP kurang banyak sehingga periklanan menjadi kurang maksimal begitu pula pembagian brosur yang kurang meluas. Penjualan melalui personal seling yang perlu diterapkan oleh Sempoa SIP Dempo Palembang demi memaksimalkan promosi. Promosi penjualan (sales promotion) dalam hal ini Sempoa SIP Dempo Palembang perlu melibatkan tenaga pengajar dalam memasarkan produk Sempoa SIP, dalam hal pameran yang rutin dilakukan oleh Sempoa SIP, Sempoa SIP perlu memilih lokasi tempat pameran yang tepat, dalam hal ini Sempoa SIP sering menggelar pameran di mall, Sempoa SIP perlu memilih mall mana yang tepat untuk Sempoa SIP memasarkan produknya dan yang terakhir yaitu publisitas, dalam hal publisitas perlu di optimalkan lagi agar tercapai nya target penjualan (jasa) perusahaan. Sempoa SIP Dempo Palembang perlu menggencarkan kegiatan promosi dimedia sosial karena di era digital seperti saat ini memasarkan produk melalui media sosial cukup efektif dan tidak perlu mengeluarkan biaya yang besar.

\section{Strategi Sumber Daya Manusia (People)}

Orang atau disebut dengan sumber daya manusia (SDM) merupakan penyedia jasa yang mempengaruhi kualitas jasa yang diberikan kepada konsumen.sumber daya manusia adalah semua orang yang dimiiki suatu perusahaan yang terlibat dalam proses penyampaian produk atau jasa kepada konnsumen. Sumber daya manusia di Sempoa SIP dikelompokan menjadi tiga yaitu, koordinator coach, coach dan administrasi, ketiganya perlu memiliki kompetensi yang yang tinggi. Karena pada pelaksanaannya mereka lah yang secara langsung menyampaikan jasa kepada para siswa sehingga tingkat puas atau tidaknya tergantung dengan cara penyampaian jasa yang dilakukan oleh para sumber daya tersebut. Untuk pemilihan sumber daya manusia Sempoa SIP Dempo Palembang melakukan dengan secermat mungkin, karena mereka lah yang akan menjadi ujung tombak dalam penyampaian jasa pendidikan kepada siswa (konsumen). Strategi untuk meningkatkan kualitas SDM yang perlu diterapkan oleh Sempoa SIP Dempo Palembang ialah memotivasi dan memberikan semangat bagi karyawan dan .membuat nuansa kantor seperti rumah sehingga sistem kekeluargaan sangat erat hal ini memotivasi karyawan untuk semangat dalam bekerja selain itu, pemberian imbalan berupa gaji dan bonus juga dinilai ampuh untuk memberikan semangat bekerja bagi karyawan. Pemberian bonus disini misalnya tenaga pengajar ataukaryawan Sempoa Sip mampu mendatangkan konsumen untuk bergabung dengan Sempo SIP Dempo Palembang akan diberikan bonus, hal ini perlu dilakukan agar bertambahnya jumlah siswa yang bergabung dengan Sempoa SIP Dempo Palembang. 


\section{Strategi Proses}

Dalam hal ini Sempoa SIP Dempo Palembang cukup baik dalam segi memberikan proses pelayanan baik dalam proses belajar mengajar maupun dalam memberikan pelayanan terhadap wali murid dengan memberikan pelayanan fasilitas yang akan membuat siswa dan wali murid merasa nyaman dan aman, karena fasilitas yang diberikan cukup memadai.Sempoa SIP dempo palembang perlu memotivasi para karyawannya agar terciptanya pelayanan dan proses belajar mengajar yang baik.

\section{Startegi Sarana Fisik (Physical Evidence)}

Berdasarkan hasil penelitian bahwa unsur bukti fisik di Sempoa SIP Dempo Palembang yang berupa bangunan atau gedung dan segala sarana dan fasilitasyang ada didalamnya cukup memadai, dimana hal ini dapat menarik minat konsumen untuk bergabung dengan Sempoa SIP Dempo Palembang. Sarana fisik yang di sediakan cukup baik dimana, sarana fisik yang dapat menunjang kegiatan proses belajar mengajar bisa dikatakan sangat baik, karena Sempoa SIP Dempo Palembang berusaha membuat nyaman baik dari siswa maupun dari pengajar (karyawan) hal ini di tujukan agar terciptanya kegiatan proses belajar mengajar yang baik.

\section{E. KESIMPULAN DAN SARAN}

Dalam hal bauran pemasaran, Sempoa SIP Dempo Palembang sudah mengikuti langkah-langkah strategi pemasaran cukup baik dalam hal bauran pemasaran. Dalam hal strategi produk, place, people, process, dan physical evidence, Sempoa SIP Dempo Palembang sudah cukup baik. Namun, terdapat beberapa hal yang perlu ditingkatkan oleh perusahaan untuk startegi pemasaran dalam hal price dan promotion. Perusahaan harus dapat memanfaatkan sarana digital untuk dapat menjangkau lebih banyak calon anak didik. Selain itu branding berupa spanduk dan banner juga harus dapat dimaksimalkan. Perusahaan juga perlu mengevaluasi pricing agar dapat bersaing lebih baik lagi .

\section{DAFTAR PUSTAKA}

Kereh Feibe. Tumbel, Altje L. Loindong, Sjendry S.R. 2018. Analisis strategi pemasaran dalam meningkatkan penjualan motor Yamaha Mio pada PT. Hasjrat Abadi Yamaha Sam Ratulangi. Jurnal EMBA. Vol. 6 No. 2. ISSN: 23031174. April $2018 . \quad$ Hal 968-977. http://ejournal.unsrat.ac.id/index.php/emba/article/view/20024. Diakses Juni $\underline{2021}$

Kotler, Philip dan Gray Amstrong Penerjemah Alexander Sindoro. 2004. Dasar-Dasar Pemasaran. Edisi ke-9, Jilid 1. Jakarta : PT Indeks.

Kotler, Philip dan Kevin Lane Keller. 2009. Manajemen Pemasaran. Edisi Ketiga Belas Jilid. Erlangga. 
Lupiyoadi, R dan Hamdani, A. 2006. Manajemen Pemasaran Jasa Edisi 2. Penerbit Salemba Empat. Jakarta.

Monigir, L., Mandey, S. L dan Ogi I. W. 2016. Penerapan Strategi Pemasaran Untuk Mencapai Keunggulan Bersaing (Studi Kasus Pada MultiMart Ranotana Manado). Jurnal EMBA. Vo. 4 No. 4. ISSN 2303-1174. Desember 2016. http://ejournal.unsrat.ac.id/indeks.php/emba/article/view/14533. Diakses Juni 2021.

Schiffman dan Kanuk, Amelia. 2008. Perilaku Konsumen. Edisi 7. Jakarta: Indeks.

Setiadi J, Nugroho. 2010. Perilaku Konsumen Perspektif Kontemporer \{ada Motif, Tujuan, Dan Keinginan Konsumen. Jakarta. Kencana Prenada Media Grup.

Silvana. 2012. Penerapan Strategi Pemasaran Marketing Mix (Studi Kasus pada PT. Batik Dinar Hadi). Widya Teknika. Vol. 20 No. 1. Maret 2012. ISSN 1411-0660. http://publishungwidyagama.ac.id/ejounalv2/index.php/widyateknika/articles/vie wFile/8/8. Diakses tanggal Juni 2021. Hal 55-62.

Swastha, Basu dan Ibnu Sukotjo W. 2002 . Pengantar Bisnis Modern. Edisi Ketiga. Liberty. Yogyakarta. 